\title{
DESIGN FOR A MEDICAL SERVICE: PETER THE GREAT'S ADMIRALTY REGULATIONS (1722)
}

by

\section{BASIL HAIGH*}

AFTER a long period of neglect the history of Russian medicine is at last beginning to attract the attention of Western scholars, ${ }^{1}$ although so far most of the new interest has been shown by social historians who have been chiefly concerned with the effects of disease and of unsanitary conditions on the economic and social development of the Russian state. ${ }^{2,3}$ Indeed, the medical aspects of Russian history provide a rich field for the social historian, rich as regards both the nature and quantity of the available material and the diversity of possible approaches and interpretations.

There is also ample opportunity in this field for the medical historian concerned with integrating the facts of the development of medical art and science in Russia into the global pattern of medical history. Because of the inadequate attention that has so far been paid to the evolution of certain branches of preventive and curative medicine in Russia, and not least by Russian medical historians, there is a real need at this stage for a careful examination and enunciation of the basic facts of the problem and for the formulation of primary conclusions.

In the course of a recent study of the origins of industrial medicine in Russia ${ }^{4}$ it became clear that nowhere is this more true than in the earliest attempt to provide a medical service for the industrial worker in Russia: that organized by Peter the Great on behalf of his sailors and dockyard workers.

This paper is devoted to a brief outline of the events leading up to the publication of Peter the Great's Admiralty Regulations of 1722, to a translation of the provisions of the Regulations relating to the medical arrangements for dockyard workers, and to an analysis of the derivation of these provisions. Those sections of the Regulations that apply specifically to the fleet at sea are not included. Although the Admiralty

*Basil Haigh, M.A., M.D., F.I.L., 28 Roman Hill, Barton, Cambridge CB3 7AX.

1The organization and recruitment of the medical service under Peter the Great have been surveyed by V. Steinfeldt, in her thesis: Das Russische Medizinalwesen unter Peter den Grossen, Bonn, 1968, and more briefly by J. T. Alexander, 'Medical developments in Petrine Russia', Canadian-American Slavic Studies, 1974, 8(2): 198-221.

$\therefore$ R. E. McGrew, Russia and the cholera, 1823-1832, Madison, University of Wisconsin Press, 1965.

J. T. Alexander, 'Catherine II, bubonic plague, and the problem of industry in Moscow', Amer. hist. Rev., 1974, 79: 637-671.

- B. Haigh, 'The early development of industrial medicine in Russia', unpublished dissertation for the M.D. degree of the University of Cambridge, 1974. 


\section{Basil Haigh}

Regulations themselves are published and are readily available, ${ }^{5}$ I am unaware of any previous translation of the medical provisions into English or of any previous categorical identification of the source from which they were derived.

Soon after the foundation of St. Petersburg in 1703 industrial development began to take place there. Naturally much of this was devoted to the equipping of the armed forces for the Swedish wars, and in 1709-1711 two of the largest industrial combines in the country were established for this purpose: the Artillery, with its smithies and workshops for the manufacture of cannons and light weapons, and the Admiralty, with its shipyards, sawmills and ropewalks. ${ }^{6}$

The Admiralty Dockyard was built in 1705-1707 and it included among its buildings a hospital to serve the dockyard workers as well as the sailors of the Baltic Fleet. Some idea of the size and layout of this establishment can be obtained from the contemporary print illustrated in Figure 1.

As the Russian navy grew and developed, so also did the need for a system of regulations for its administration and conduct. In the beginning the Tsar leaned heavily on the contemporary legislation in force in Western Europe, especially in England, France, Holland and Sweden. Voltaire makes this point clear in his History of the Russian Empire under Peter the Great.

Ce fut principalement dans l'année 1718, pendant qu'il instruisait solomnellement le procès de son fils, qu'il fit les règlemens. La plupart des loix qu'il porta, furent tirtes de celles de la Suede, et il ne fit point de difficulté d'admettre dans les tribunaux les prisonniers Suédois instruits de la jurisprudence de leur pays, et qui ayant appris la langue de l'Empire voulurent rester en Russie.'

The French and Dutch undoubtedly had the best organized system of naval administration in Europe at this period, largely owing to the genius of Colbert, and the evolution of the Russian naval regulations is based in the main on the successive adoption of those in force in those two countries. For example, the first Russian naval code, known as the "Articles" (Artikul'nyya Stat'i), was simply a translation made from the Dutch in $1668 .{ }^{8}$ However, these articles were concerned exclusively with nautical matters, and it was not until 1722 that a comprehensive code of administrative regulations to govern the activities of the Admiralty and its dockyards was published. This code has the full title of "Regulations governing the administration of the Admiralty and Dockyard and the duties of the Admiralty College and of all officials employed at the Admiralty". It is a document of great interest to the medical historian, for it describes in great detail the medical and welfare facilities required by law to be provided for the dockyard workers.

\footnotetext{
- Polnoe sobranie zakonov rossiiskoi imperii (Complete collection of laws of the Russian Empire), first series (to 1825), VI, No. 3937, 5 April 1722, St. Petersburg, 1830 (title hereafter abbreviated to PSZ-1). A complete set of this work exists in the British Library and it is also available on microfiche at Cambridge University Library.

- E. I. Zaozerskaya, Manufaktura pri Petre I (Manufacturing industry under Peter I), Moscow and Leningrad, Izdatel'stvo Akademii Nauk SSSR, 1947, p. 12.

' F.-M. Voltaire, Histoire de l'Empire de Russie sous Pierre le Grand, vol. II, Paris, 1763, p. 210.

- F. Veselago, Ocherk russkoi morskoi istorii (A sketch of Russian naval history), part I, St. Petersburg, 1875, p. 537.
} 


\section{Design for a medical service}

THE STRUCTURE OF THE REGULATIONS ${ }^{\circ}$

The Regulations are in two parts: Part 1 contains fifty-two chapters and Part 2 sixteen chapters.

Part 1 lays down the duties of the Admiralty College and of all Admiralty officials from the highest (the Commander-in-Chief) to the lowest workshop foreman and clerk. It specifies the form of the record books in which are to be inscribed the person's "name, pay, rations and other items", it establishes the number of chancellery officials, commissars and other officers, and the number of apprentices and workers to be engaged on the various jobs in the workshops at the ports of St. Petersburg, Kotlin and Revel. It is this part which is of medical interest. The other part of the Regulations is concerned with organization of the work of ships in port and the management of harbours and anchorages.

\section{SPECIFIC ITEMS OF MEDICAL AND HYGIENIC INTEREST}

The first Admiralty official mentioned in the Regulations in connexion with the medical service is the Paymaster (Kaznachei Admiralteiskii). In the chapter listing his duties we find details on payment for medical supplies and emoluments of the medical staff.

Chapter I, paragraph 34. On deduction for medicines at the rate of 1 kopek per rouble. Money deducted from the pay of every man serving in the fleet and Admiralty at the rate of 1 kopek per rouble shall be sent to the Imperial Physician (Arkhiater) for the upkeep and maintenance of the dispensaries, apothecaries and their employees in St. Petersburg and in other ports. Chapter I, paragraph 35. On payment of salaries to physicians, surgeons and others from the Admiralty. Salaries shall be paid to physicians, surgeons, apothecaries' assistants (Geseli) and apprentices (Ucheniki) from the Admiralty, in accordance with the Regulations in force in the Medical College, thrice yearly as to other employees.

\section{ITEMS DEALING WITH WORKING CONDITIONS}

Chapter XII, paragraph 32, specifies the hours of work at the Admiralty. The actual wording is given below and the length of the working day is shown diagrammatically in Figure 2 (modified from Portal). ${ }^{10}$

At what times the bell will ring to and from work: From 10 March to 10 September the bell to start work rings at 4.30 a.m.; in March and April from work at 7 p.m. and at mid-day from work at 11 a.m. and to work at 12.30 p.m.; in June and July in the morning at 4.30 and in the evening at 8 p.m.; at mid-day from work at 11 a.m. and to work at 1.30 p.m.; in August in the morning and evening and from work at mid-day the same, and to work at mid-day at 1 p.m. From 20 August to 10 September, at the same time in the morning and at mid-day, and in the evening at 7 . From 10

\footnotetext{
- The full title is Reglament o upravlenii Admiralteistva $i$ verfi $i$ chast' vtoraya Reglamenta Morskago. PSZ-1, VI, No. 3937, 5 April 1722.

${ }^{10} \mathrm{R}$. Portal, L'Oural au XVIII siecle, Paris, Institut des Etudes Slaves, 1950. A scholarly account of early industrial development in the Urals with emphasis on economic aspects.
} 


\section{Basil Haigh}

September to 10 March, in the morning 1 hour before sunrise and in the evening 1 hour after sunset (by the calendar), at mid-day from work at 11 a.m. and to work at 12 noon. For building and smithy work, from 10 September to 10 March from work in the evening at 8 p.m., and otherwise as mentioned above. But if there is no need for this work, then in the evening as mentioned above.

In peacetime, or when there is no essential work to do, masters will not work from 10 November to 10 January, and will receive no wages for work on those days.

The standard working day was thus of thirteen hours, with an extra half-hour in August and part of September. In winter, because of the short period of daylight, the hours of work were correspondingly shorter, in the absence of any adequate form of artificial lighting. At the latitude of St. Petersburg $\left(59^{\circ} 55^{\prime} \mathrm{N}\right)$ the approximate times of sunrise and sunset in late December are 9 a.m. and 3 p.m. local time respectively, so that the hours of work then would be from 8 a.m. to 11 a.m. and from 12 noon to 4 p.m.

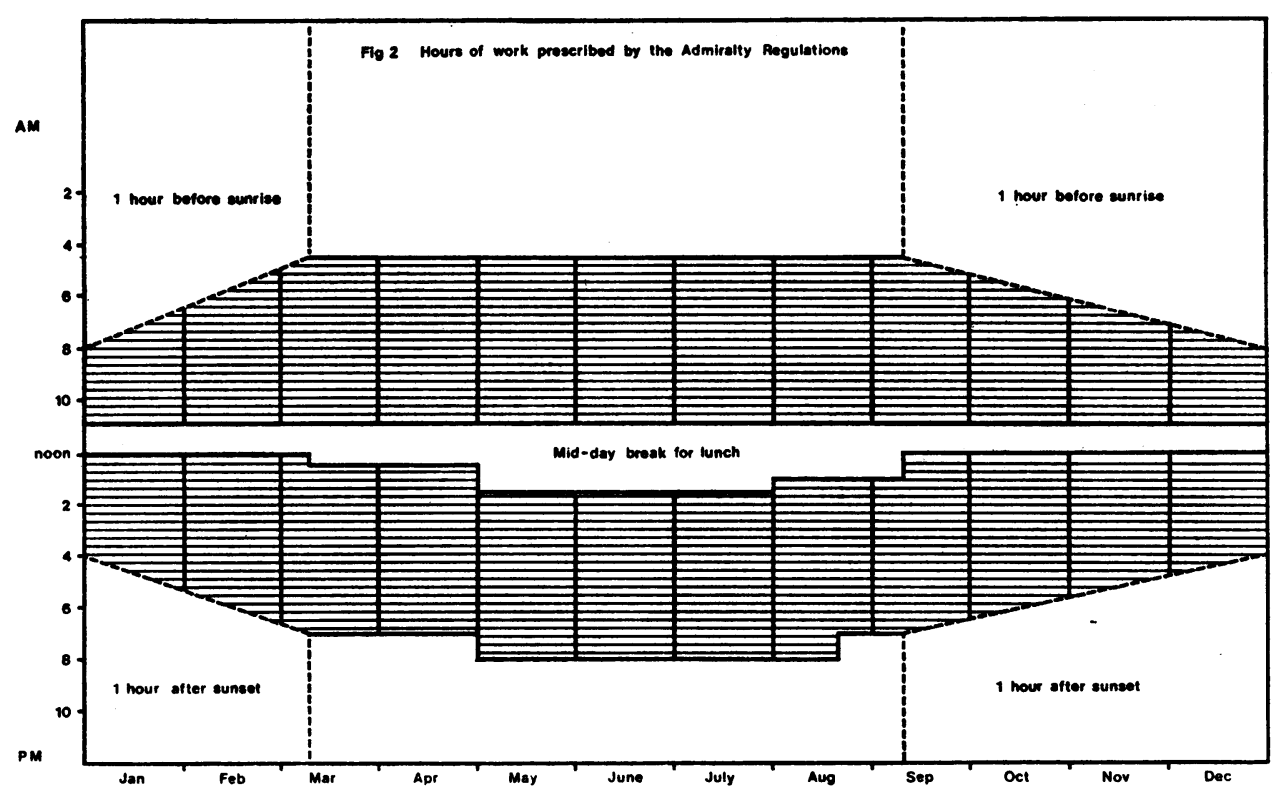

\section{RESTRICTIONS ON LIFTING}

An interesting paragraph (Chapter XI, paragraph 29) limits heavy lifting and carrying by manpower in the shipyards, though whether this is on economic or humanitarian grounds, or simply an instance of Peter's refusal to be outdone by the west is not clear.

"Nothing shall be carted or carried (except small articles which one person can carry alone) except in summer by water, because there are canals to all workplaces, and in winter on sledges drawn by horses; also, machines will be used for lifting at work, as are used in other countries; if none are available it will perhaps be possible to invent, so that the work can be done by a smaller number of people." 


\section{Design for a medical service}

The preceding paragraph (paragraph 28) specifies the number of horses to be kept for this purpose: sixty are allocated in winter for carrying timber from the forests to the St. Petersburg shipyards.

\section{ILLNESSES OR ACCIDENTS AT WORK}

The right of Admiralty employees to receive hospital treatment for injuries sustained or illnesses developing at work, his entitlement to re-employment on recovery, and the necessary administrative measures are clearly laid down in Chapter XII, paragraph 39.

When an Admiralty employee is taken ill or is injured by an accident at work, he will be sent to the hospital with a letter to the Commissar of the hospital without delay, before the illness can take hold, and a deduction will be made from his pay according to agreement; the name of the person sent and the date will be recorded. Later, on recovery, the person will be discharged from hospital with a letter from the same Commissar of the hospital; he will then be reinstated in his previous job. The duration of his stay in hospital will be recorded so that deductions can be made from his wage in accordance with Article 8 of the chapter "On Hospitals" (Chapter XLVII).

This point is further emphasized in Chapter XIII, paragraph 16:

Persons taken ill suddenly at work shall be treated. When an Admiralty employee is taken ill suddenly, or when he is injured at work in the dockyard, he is at once to be directed for treatment to the medical assistant or his wounds are dressed. An injury or disease may also occur which makes it impossible for the person to go to the medical assistant; in that case he will be sent to the hospital and a report given to the Director of the Office (Direktor nad Kontoroyu).

\section{HOSPITALS}

Chapters XLVII to LII are all concerned entirely with hospitals at the ports; since these facilities were provided as much for the dockyard workers as for the navy, it is imperative that they be examined here in detail. This section is entitled: "Rules on hospitals, and on the duties of commissars, doctors, clerks and others appointed thereto (Reglament o gospitalyakh, $i$ o dolzhnostyakh opredelennykh pri nikh Kommisarov, Doktorov, pisarei i prochikh)."

\section{Chapter XLVII: On hospitals}

1. At ports to be hospitals, and Commissars in them. At ports everywhere there shall be hospitals, with Commissars in charge of them, under the direction of the Commissar-General for War (General-Krigs-Kommisar).

2. The sick in hospitals to be looked after and kept as the Rules stipulate. The sick in hospitals must be looked after, in medicines, food, and also in rest and cleanliness, and they must be kept as laid down by the Regulations.

3. Doctors to be at all hospitals. At each hospital there shall be one doctor to treat the sick.

4. On senior surgeons (starshikh lekaryakh) at each hospital and the number of apothecaries' assistants and pupils. At each hospital there shall be one senior surgeon, who shall have command over the other surgeons. There shall be sufficient surgeons (lekarei) to provide one for every 200 patients. They shall each have two apothecaries' assistants (gezelei lekarskikh) and four pupils (uchenikov). The senior surgeon, two apothecaries' assistants and the pupils will all live at the hospital. The pupils will also be given food at the hospital. 


\section{Basil Haigh}

5. Churches and priests at hospitals. At each hospital there shall be a church and one priest, who shall conduct divine service, comfort the sick, hear their confessions, administer communion, and guide them in all matters.

6. Who shall be admitted to hospital. Nobody shall be admitted to hospital except Admiralty employees, members of the forces, and masters and workmen falling ill or becoming injured while fighting or at work.

7. The medicine chest and apothecaries' assistant in charge of it on the dockyard. On the dockyard there shall be one small medicine chest (sunduk lekarskii) with an apothecaries' assistant (gezel) for sudden illnesses and injuries affecting Admiralty employees at work.

8. Retention of half the monetary wages and all the rations of persons kept in the hospital. Half the monetary wages and all the rations of persons kept in hospital shall be retained during the whole of their stay in hospital, and the retained half of the money shall be used for maintaining the hospital, while the rest is given to the patient on his discharge from hospital; the rations are credited to the hospital account.

9. Contract for the supplying of bread and meat to the hospital. Baked bread and fresh meat shall be supplied for patients kept in hospitals, and arrangements for this shall be made with the tradesmen to provide as much as is required for the whole year, fixing an average price.

10. The number of female workers at hospitals. Female workers shall be employed at hospitals to wash the linen and all the patients' clothing, in the number given below depending on the nature of the illnesses:

$\begin{array}{lll}\text { for } 20 \text { patients with severe diarrhoea } & 1 \text { woman } \\ \text { for } 30 \text { " " moderately severe diarrhoea } & 1 \text { woman } \\ \text { for } 40 \text { " " } \quad \begin{array}{l}\text { severe illnesses other than diarrhoea } \\ \text { for } 50 \text { " } 1 \text { woman }\end{array} & \begin{array}{l}\text { moderately severe other illnesses and } \\ \text { with mild illnesses }\end{array} & 1 \text { woman }\end{array}$

To look after the linen and supervise the female workers there shall be one nun (staritsa) at each hospital, with one assistant from among the older women at the convent, replaced annually.

11. The number of male workers at hospitals. There shall be the undermentioned number of male workers depending on the nature of the patients' illnesses, as follows:

for 10 patients with severe diarrhoea

for 20 " moderately severe diarrhoea

for 15 moderately ill patients with other diseases, who can walk unaided only a little,

and for those with mild illnesses

Their duties shall be as follows:

1. To attend to all the needs of the sick.

2. To heat the sick wards and keep them clean.

3. To help the nurses by carrying and heating water, etc.
2 men

3 men

1 man

For the kitchen there are cooks and workers, as many as necessary, in addition to to the number stated above.

12. On the clerk at each hospital and his assistants. At each hospital there shall be 


\section{Design for a medical service}

one clerk, who shall be responsible for all clerical duties thereat, and he shall be assisted by two copyists.

13. On dispensaries and apothecaries at each hospital. At the St. Petersburg Hospital there shall be the Chief Dispensary for the fleet and for the sick. At other hospitals, each will have its own dispensary, its quality decided by the Imperial Physician (Arkhiater), with the necessary number of employees at the dispensary.

14. On linen, rags, wine and vinegar in hospitals. Linen and rags for bandages, compresses and lint, also wine and vinegar for fomentations and other uses are kept at hospitals by the Commissars.

15. On bedding and other linen for patients. Beds are provided in the hospitals for the sick as follows: hair mattresses and round pillows covered with ticking for those who are seriously or moderately seriously ill, and thin straw mattresses placed on top of these beds for those with diarrhoea. For patients with mild illnesses, straw is bound four or five inches thick, and above it is placed felt covered with coarse cloth. Round hair pillows are covered with coarse cloth.

Blankets of grey cloth, with white sheets tacked on. Linen sheets on beds for all patients. Shirts and trousers: three changes for patients with diarrhoea and two for the rest.

Linen is changed: daily for patients with diarrhoea; once or twice a week for the others, depending on their illnesses; for those with venereal diseases it is changed as ordered by the doctor or surgeon at the hospital.

16. On utensils and other articles for the sick. The following utensils will be provided for the patients. Copper pans for cooking, large enough to cook for fifty persons and for two persons to carry them with food, with high edges so that they do not splash, with covers, and always tinned; and other small vessels, iron skimmers, and pronged implements with which to remove meat.

The kitchen is to be situated in the middle of the hospital so that the food will be carried the same distance in all directions; in it there are end-irons on which to rest the pans, and other implements used in cooking.

For serving the food to the sick there will be pewter dishes, and for those who cannot leave their beds a small dish for each, and for those who can walk to the table one bowl for seven persons, wooden plates, spoons for each, and one knife between two.

Linen tablecloths, but instead of napkins, pieces of linen cloth sewn around the tablecloth.

Thick glass salt cellars, one to seven persons.

For drinking, wooden jugs for those who can walk to the table, one to seven persons; for those who cannot leave their beds small jugs, one between two persons, and ladles.

For meals, candlesticks with snuffers, one to every three bowls, but one between two persons if they are seriously ill.

Tables at which the patients eat, also benches around the tables. And for seriously ill patients one small table next to each bed.

At night, one lamp to each ward.

Tubs, troughs, buckets, pails, etc., and soap and ashes for washing the linen and utensils, depending on the quality of the linen and utensils. 


\section{Basil Haigh}

Also firewood and candles, depending on the number of stoves and candlesticks. 17. On food for the sick. Meals for the sick are given twice daily. In spring, winter and late autumn, oatmeal porridge or barley porridge with fresh butter, and in summer and early autumn, as long as vegetables are available, they will eat cabbage, goutweed, nettles and other greens, alternating with porridge and as ordered by the doctor or surgeon.

Patients who are not allowed to have meat are given white bread with liquid porridge, subject to inspection by the doctor.

Well-cooked kvass at all times, but beer, wine and kvass for drinking must be given only at the doctor's or surgeon's discretion.

\section{DAILY RATIONS ALLOWED FOR COOKING FOR PATIENTS}

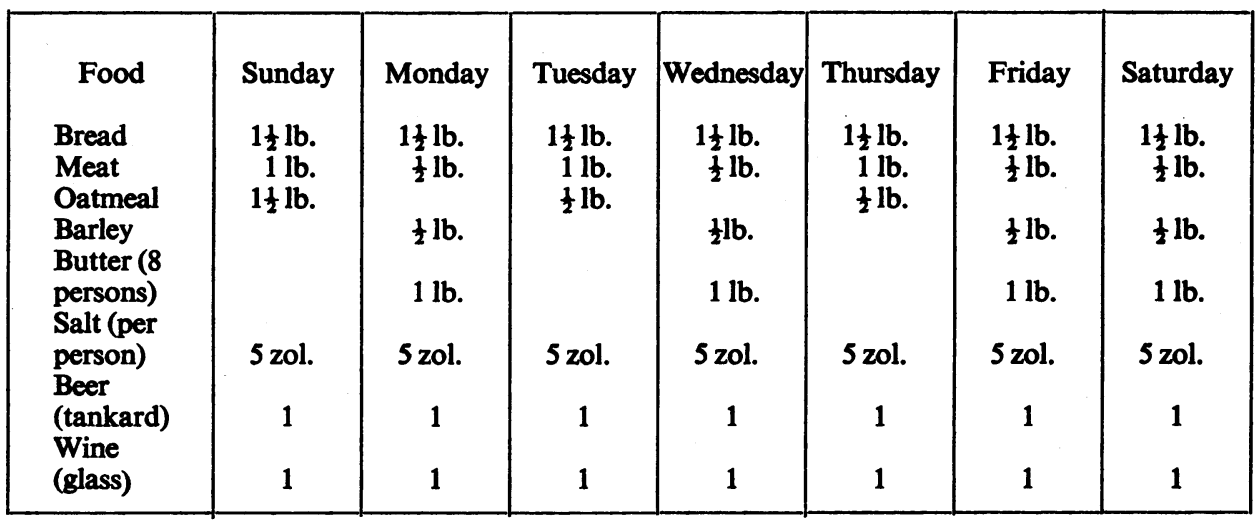

Note: zol.=zolotnik; 96 zolotniki=1 Russian pound.

18. On baths and ice-houses for the sick. There will be baths and ice-houses, and ice will be put in the ice-houses for the summer time; also a brewhouse for making beer and kvass, as much as is required, and the necessary utensils; in summer time the beer, kvass, etc., will be kept on ice.

19. On cows for the sick. Several cows will be kept to provide milk for the sick as a food and a medicine, and they will be fed on grain left from brewing beer and kvass. 20. On vegetable gardens. Also at every hospital there will be a vegetable garden for food for the patients and for the dispensary.

\section{Chapter XLVIII: Duties of Commissars over hospitals}

1. On admission of patients to hospital and their discharge when cured, and on reports about the sick. Patients are admitted to hospital as described in paragraph 6 of the chapter "On hospitals", with letters from their commanders giving the date on which they are sent, and with a certificate signed by the doctor or senior surgeon that they are genuinely ill. Commissars must ensure strictly that patients, when they have recovered and regained their strength, are not kept in hospital but sent back where they belong, taking with them a similar certificate from the doctor or surgeon to that brought on admission. Information on admission and discharge will also be sent to the Commissar General for War, in the case of naval personnel, or to someone 


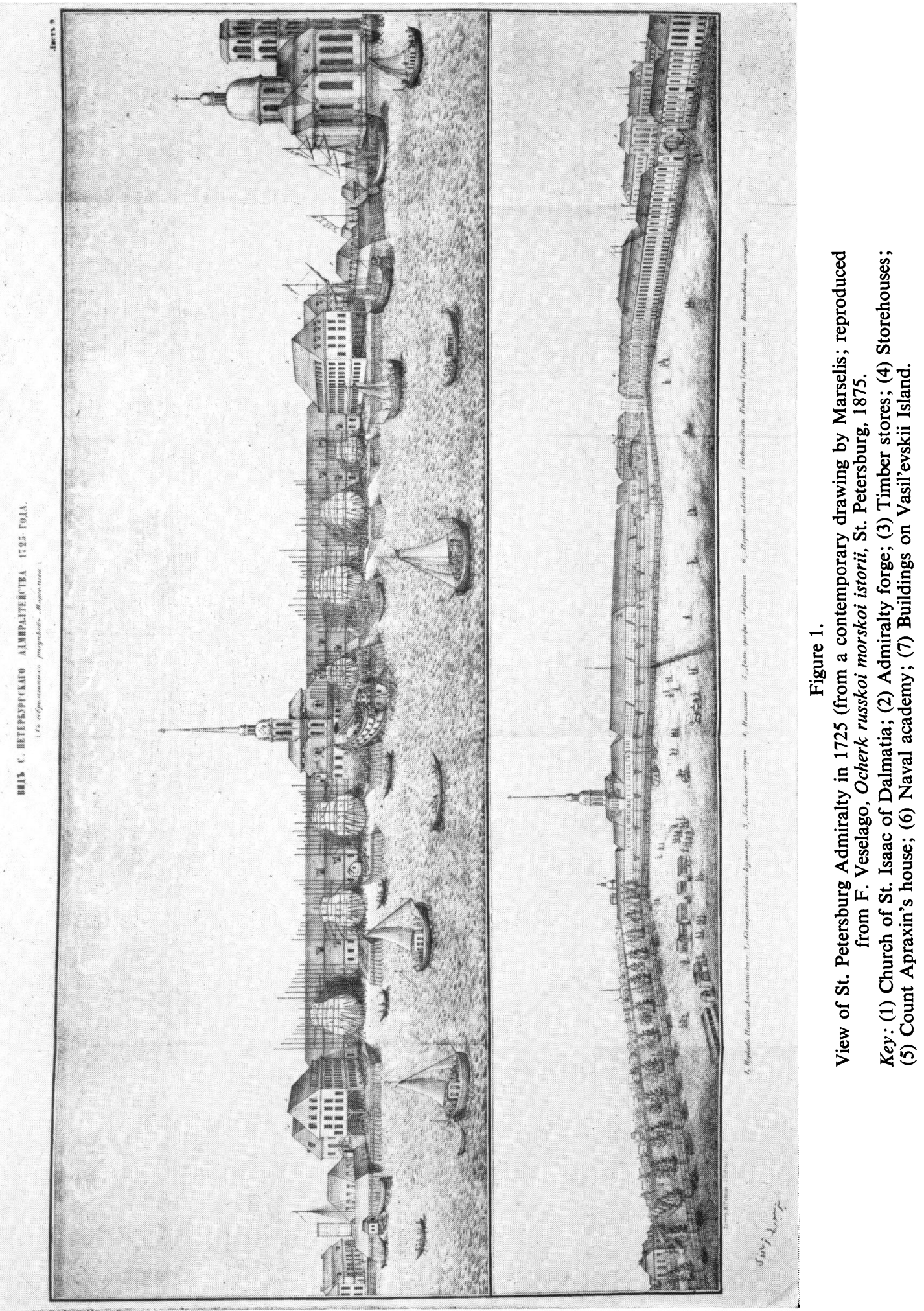




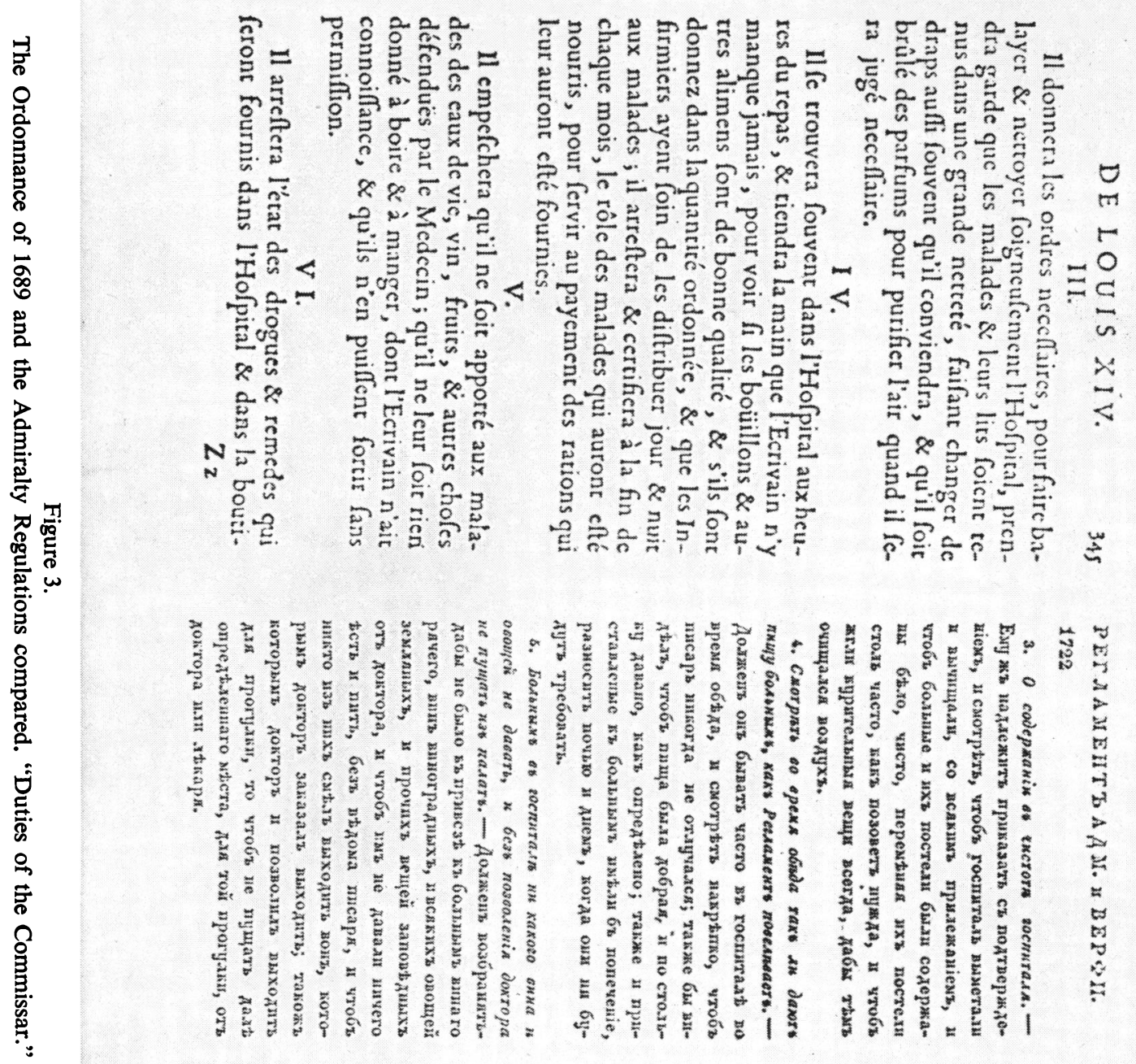




\section{Design for a medical service}

appointed in his place; in the case of Admiralty employees and master workmen in St. Petersburg to the Admiralty Office, and in other ports to the Chief Commandant of the Port, so that deductions can be made from their pay as described in paragraph 8 of the chapter "On hospitals". The number and condition of the patients will also be reported to him each week. Monthly reports are made to the Admiralty College and to the Imperial Physician, countersigned by the Commissar and Clerk and by the Physician and the First Surgeon at the hospital.

2. On records of patients in hospital and on the need to start their treatment without delay. Care must be taken that the Hospital Clerk's book is always correctly filled up with the following details of the patients admitted: the place from which they were sent, their occupation, the circumstances of their illness, the dates of admission and discharge, and whether the latter was because of cure or death, so that the time during which they were being kept at the hospital's expense is known. The Commissar must also keep careful watch to ensure that when sick persons are sent to him they are taken into hospital and their treatment started without delay, under penalty of a deduction from pay, at the College's discretion, both for delay in admitting the sick to hospital and for not seeing that they are sent back to where they belong when they have recovered.

3. On keeping the hospital in a clean condition. The Commissar must order, and see that the order is carried out, that the hospital is swept out and cleaned diligently, that the patients and their beds are kept white and clean, with their beds changed as often as is necessary, and that fumigating materials are constantly burned in order to purify the air.

4. Inspection during mealtimes that food is given to the sick as laid down by the rules. The Commissar must frequently be at the hospital during mealtimes and must ensure that the Clerk never absents himself; he must also see that the food is good and that the specified amount is given; also that items prescribed for the patients are distributed by night and day, when required.

5. Patients in hospital must not be given wine or vegetables, and must not leave the ward, without the doctor's permission. The Commissar must not allow spirits or wines to be brought for the sick, or any vegetables or other articles forbidden by the doctor, and he must ensure that they are given nothing to eat or drink without the Clerk's knowledge, and that no patient goes out who has been forbidden by the doctor to do so; also that those persons who are permitted by the doctor to go out for walks do not go further than the place specified by the doctor or surgeon for their walk. 6. All patients' chattels and money will be kept by the Hospital Clerk. The Commissar must entrust to the Clerk the chattels and money belonging to the sick or wounded who are admitted to hospital, who must put them in safe keeping so that they can be given back in their entirety when the patients are discharged, or given in the event of their death to their next-of-kin or creditors. If no next-of-kin or creditors are found, the clothes will be sold, and the money realized, together with money found in the pockets, will be used as laid down by the College's instructions, in the hospital. [Item 7 deals with hospital ships.]

8. Supervision of orderlies assigned to the sick. The Commissar must supervise the orderlies who will be chosen and appointed by the Admiralty College for nursing 


\section{Basil Haigh}

the sick and wounded admitted to the hospitals, for whom the Clerk will keep a register recording their appointment, their leave, wages and rations; their status must be described and confirmed at the end of each four months, so that their pay and rations can be awarded.

9. Daily reports on the state of the hospital. The Commissar must give a true report every day to the Chief Commandant of the Port and to the Commissar General for War, of everything pertaining to his duties and of events taking place (deaths) in the hospital, of the treatments carried out, of the fulfilment of His Majesty's ukases for the regulation of good order and for the hospital expenses; the Commissar at the St. Petersburg hospital will report daily to the Admiralty College and to the Commissar General for War.

10. Holding monies assigned to the hospital and their disbursement. The Commissar will hold funds assigned to the hospital and he will use them with the confirmation of the Chief Commandant of the Port, the Chief Commissar for War (Ober-KrigsKommisar), and in St. Petersburg, with the confirmation of the Commissar General for War.

11. Contracts and purchases to be executed in accordance with the Admiralty Code. Major contracts and purchases with respect to all articles in hospitals shall be executed in the manner prescribed by the College, in ports by the Chief Commandant and Chief Commissar for War, and in St. Petersburg by the Commissar General for War, and 100 roubles shall be held for petty expenses. And when an expense is incurred, details shall be given to the Chief Commandant and Chief Commissar for War in ports, and to the Commissar General for War in St. Petersburg.

12. Money shall be received and distributed, and expenditure recorded, and the book for the whole year shall be sent to the College for accounting. Monies and all articles received and distributed will be recorded in a book, and the books of receipts and disbursements will be sent annually to the Admiralty College for accounting as prescribed, to the Admiralty Paymaster and to the Officer in charge of stores, excluding those orders sent out from the Admiralty Office on receipts and payments.

13. Provisions for the sick to be under the Hospital Commissar's charge. All provisions for the sick must be under his charge, and whatever is ordered from the Admiralty Stores will be received therefrom monthly. What is to be obtained by contract is negotiated in St. Petersburg with the Commissar General for War, and in other ports with the Chief Commandant and the Chief Commissar for War, and the provisions are to be used in the hospital as specified in the Table (Chapter XLVII, paragraph 17) and at the Doctor's discretion.

\section{Chapter XLIX: Duties of clerks appointed to Hospitals}

1. On their presence at the hospital permanently and on reception of the sick. The clerk appointed to the hospital must be there permanently and must not admit any sick or wounded person without instruction from the Commissar, who is responsible for this matter, unless for some necessary reason such a person is sent to him in the Commissar's absence, when he will be admitted with the certificate specified in the chapter on "Duties of Commissars"; in that case the Clerk must inform the Commissar as soon as possible of the date of admission and enrolment. 


\section{Design for a medical service}

2. Patients' records. The names of the sick and wounded who enter the hospital are to be recorded with all circumstances relevant in the sewn book, and certified copies of each page will be sent to the Admiralty College, stating from whence and by whom they were sent, their position, the nature of their illness or wound, from the day of admission to the day of departure, whether this be due to cure or death. 3. Issuing of linen and bedding to patients and care of their personal clothing. The Clerk will ensure that bedding is issued in accordance with the nature of the illness as specified in paragraph 15 of the chapter "On hospitals", and shirts and trousers when the previous ones are worn out. He must make a list of their chattels and money, which he must take himself, order their linen to be washed and their overcoats cleaned, and the owners' names to be sewn on them; all are to be kept for giving back on receipt of the order from the Hospital Commissar.

4. Keeping the hospital clean. The Clerk must order the hospital to be swept and cleaned every day before Mass and he must take diligent steps to ensure that it is kept very clean, and that the patients do not lie in filth, for which purpose he must order linen and sheets to be issued as often as is stipulated by paragraph 13 of the chapter "On hospitals".

5. The Clerk must see that medicine is given to the sick as prescribed by the Doctor. When the Doctor or Chief Surgeon at the hospital attaches prescriptions for medicines for each patient to his bed, the Clerk must ensure that the apothecaries' assistant gives the medicines in accordance with the prescriptions. He must also see that the apothecaries give out the prescribed medicines without delay, and that dressings are applied to the wounds and that the patients are carefully bandaged.

6. The Clerk must inspect patients' food and note the portions every day. He must be present every day at the patients' mealtimes in order to see whether food is given to them regularly and in the amounts stipulated. He must also note in the book every day how much money is spent on food and the number of portions issued, and report to the Commissar, who must countersign the entry in the book so that what has been issued and what must be paid for it are known.

7. Record of persons employed in the hospital. The Clerk must also keep a true book record of the persons employed in the hospital, including the date of appointment and the date of dismissal, with the wages paid to them, and every four months he must show this book to the Commissar to obtain authorization for payment of wages and the issuing of rations for the employees.

8. He must see that nobody brings food or drink to patients except that ordered by the doctor. The Clerk must watch that no food or drink is brought to the patients except that ordered by the Doctor at his discretion.

9. Record of inventories of hospital linen and instruments. The Clerk must keep a list of inventories of the hospital linen and instruments and he must see that they are properly kept and cleaned to remove anything deposited on them, and that they are not worn out and unfit for use.

10. Receipt of linen, rags, wine and vinegar from the Commissar and their distribution to Surgeons and Apothecaries' Assistants. Linen, rags for bandages and compresses, and wine and vinegar for poultices and other uses must be drawn from the Commissar weekly from the list, and distributed room by room to the Surgeons and 


\section{Basil Haigh}

Apothecaries' Assistants, whenever they are ordered and required, together with lists; he must also see that they are not uselessly wasted, and that those which can be used again are washed and kept in a clean condition.

11. All worn-out linen to be returned to the Admiralty Office. All worn-out shirts and other linen, if unfit for any use in hospital, will be returned, when so certified by the Hospital Commissar, in St. Petersburg to the Admiralty Office and in other ports to the Port Captain.

12. Confirmation of reports made on patients by the Commissar. The Clerk must confirm all reports on patients made by the Commissar of the Hospital in accordance with paragraph 1 of the chapter "Duties of Commissars over hospitals", for submission in St. Petersburg to the Admiralty College, the Commissar General for War, the Admiralty Office and the Imperial Physician, and in other ports to the Chief Commandant of the Port and the Chief Commissar for War.

\section{Chapter L: Duties of Physicians at Hospitals}

1. Visiting the sick. The Physician must visit the sick and wounded in hospital, together with the Chief Surgeon, every morning and evening, and more often if necessary, and he must inspect how the wounded are bandaged.

4. Admission of the sick to special places, and charts on which food and medicines for each patient are prescribed. The Physician must order the sick to be accommodated in separate places for each disease, clearly numbered, so that their treatment will be more conveniently carried out. The wounded will be separated in the same way, and the Physician must order the Surgeons to keep a book in which are written the patient's name, his service number, and his illness, which he will countersign, and he will write on the charts or on thick paper schedules, which can conveniently be pasted to each patient's bed, indicating the medicines to be given, and other charts indicating the food to be given to any patient who is to receive a special diet.

5. Inspect the dispensary to see that medicines are correctly made up. The Physician must inspect the dispensary to see that medicines are well compounded and of good quality, and have not lost their strength, and that the apothecary works with care and with all due accuracy.

6. Verify the record of medicines kept by the apothecary against prescriptions. When the apothecary makes up medicines from prescriptions and issues them he will record these matters in a book; on every eighth day the Physician must check this record in the book for the previous week against his prescriptions, and confirm that he has done so with his signature.

7. On examination of patients sent to hospital to see that they are genuinely ill and, when they recover, to certify this to the Commissar of the hospital. The Physician must examine the sick and wounded when they have recovered and certify this information to the Commissar of the hospital by his signature. He must also examine persons who have come to the hospital to see whether they are genuinely ill, and not pretending to be so, and he must certify this also in writing to the Commissar.

8. Extraordinary illnesses to be noted and news of them sent to the Imperial Physician. If certain diseases are of special interest, the Hospital Physician will notify them and send the details to the Imperial Physician, for better discussion with the College. 


\section{Design for a medical service}

9. At what times he must be at the hospital. The Physician will be at the hospital at seven o'clock in the morning and at five o'clock in the afternoon, and he will order the bell to be rung, when all employees must assemble at their places, and the Physician and others will start to conduct their business.

10. On anatomical dissection of human bodies. The Physician will often perform anatomical dissections of human bodies in the ward used for that purpose in the hospital, which will be attended by the Surgeons, Assistants and Pupils; he must discourse on all parts of the body and on the diseases, the medicines suitable for these diseases and, in particular, on strange diseases, for which anatomical examinations must never be omitted, and a report sent to the Imperial Physician.

11. On reporting the state of the hospital to the Imperial Physician. The Physician must report on the whole state of the hospital and dispensary and the employees to the Imperial Physician, and all the information that is required about it must be supplied to him.

12. Confirmation of all reports on patients submitted by the Commissar. The Physician must confirm all reports about patients for submission to the College, the Commissar General for War, the Admiralty Office and the Imperial Physician, in the case of St. Petersburg, and to the Chief Commandant of the Port and the Chief Commissar for War at other ports, in accordance with paragraph 1 of the chapter "Duties of Commissars over hospitals".

\section{Chapter LI: Duties of the Chief Surgeon at the hospital}

1. He must be at the hospital at the stipulated time and supervise the Surgeons, the Students and the Apothecaries' Assistants. The Chief Surgeon (Glavnyi Lekar') must be at his work twice a day at definite times, when he will visit the patients when the bell rings, and perform his duties, and also at other times if a patient requires him, and he must report everything to the Physician and request his decision. He must also supervise the Surgeons, Students and Apothecaries' Assistants, to ensure that they do their work properly, and report on all these matters to the Physician.

2. Establishment of a rota in the hospital for Surgeons, Apothecaries' Assistants and Students. A rota for the Surgeons, Apothecaries' Assistants and Students must be drawn up so that a certain number of them will be present at all times at the hospital to deal with emergencies affecting the sick.

3. He will accompany the Physician at inspection of the medicines in the Dispensary. The Surgeon must be present when the Physician inspects the medicines in the Dispensary and examine the plasters and ointments and other articles pertaining to his work, and if he should see any which are unfit for use he must inform the Physician accordingly.

5. If so instructed by the Physician he must carry out post-mortem examinations.

6. Countersign reports submitted by the Commissar of the hospital. The Surgeon must certify all reports on patients for submission in St. Petersburg to the Admiralty College, the Commissar General of War, and the Admiralty office and Imperial Physician, and in other ports to the Chief Commandant of the port and the Chief Commissar for War, by the Commissar of the Hospital in accordance with paragraph 1 of the chapter "On duties of Commissars over hospitals". 


\section{Basil Haigh}

7. In the Physician's absence, when necessary he must do the Physician's work.

\section{Chapter LII: Duties of the Apothecary at the Hospital}

1. He must keep medicines in good order and safety. The Apothecary must keep the dispensary in good order according to the Regulations issued by the Imperial Physician, and keep the medicines safely, so that they are fresh and do not lose their strength, and that there is a sufficiency of them.

2. He must send medicines according to the Physician's prescriptions. Medicines according to the Physician's prescriptions must be sent without delay, and nothing other than what is written on the prescription shall be used.

4. He shall not use spoiled medicines, nor keep them, but discard them. Medicines which are spoiled must not be used or kept in the dispensary but, on certification by the above-mentioned doctors, they shall be discarded and the Imperial Physician notified.

5. Use of good medicines in the Dispensary. When, by command of the Imperial Physician, the Apothecary uses medicines from the dispensary, he shall use good ones, never bad, and he must give an account of the circumstances if bad ones are used, under penalty of a heavy fine.

6. He will record the receipt and consumption of medicines and account for them to the Imperial Physician. All receipts and issuings of medicines must be recorded in books with stamped and marked pages, obtained from the Imperial Physician, and from the receipts, withdrawals, and amount left in stock, an account is rendered to the Imperial Physician.

This concludes the description of those items of the Admiralty Regulations that relate to the medical service for the navy on shore and also, more particularly, for the shipbuilding workers at what were among the largest industrial units in Russia at that time.

As I shall mention later, the provisions of the Regulations served as a model for other factories. Before examining the fate of these Regulations, however, we must study their origin, an interesting historical fact on its own account.

\section{ORIGIN OF THE ADMIRALTY REGULATIONS}

The influence of Western European naval regulations on those formulated by Peter the Great for his own use has been mentioned. The extent to which Peter borrowed from the French "Ordonnances" will be clear from the comparison given below.

The "Ordonnance of Louis XIV for the Navies and Marine Arsenals" was published in Paris in 1689.11 The Ordonnance is divided into Books, and Book 20 is entitled "Des Hospitaux des Armées Navales et dans les Ports, comme aussi des Seminaires établis pour leur Direction, et pour celles des Aumôniers des Vaissaux". This Book is divided into "Titres" and the first eight Titres are concerned with medical matters. The titles themselves are compared below with the corresponding chapters of the Russian Admiralty Regulations.

11 Ordonnance de Louis XIV pour les armées navales et arcénaux de marine. Avec privilège de Sa Majesté. Paris, chez Estienne Michallet, 1689. 
Design for a medical service

Ordonnance de Louis XIV

Admiralty Regulations

\begin{tabular}{|c|c|c|c|}
\hline Titre & Wording & Chapter & Wording \\
\hline 1 & $\begin{array}{l}\text { Des Hospitaux a la Suite des } \\
\text { Armées Navales ou Escadres }\end{array}$ & & \\
\hline 2 & $\begin{array}{l}\text { Des Hospitaux établis dans les } \\
\text { Ports }\end{array}$ & XLVII & On Hospitals \\
\hline 3 & $\begin{array}{l}\text { Du Commissaire préposé à la } \\
\text { direction de l'Hospital }\end{array}$ & XLVIII & $\begin{array}{l}\text { Duties of Commissars over } \\
\text { Hospitals }\end{array}$ \\
\hline 4 & $\begin{array}{l}\text { De l'Ecrivain du Roy établi } \\
\text { dans l'Hópital }\end{array}$ & XLIX & $\begin{array}{l}\text { Duties of Clerks appointed to } \\
\text { Hospitals }\end{array}$ \\
\hline 5 & $\begin{array}{l}\text { Du Médecin entretenu dans le } \\
\text { Port }\end{array}$ & $\mathbf{L}$ & Duties of Physicians at Hospitals \\
\hline 6 & $\begin{array}{l}\text { Du Médecin de l'Hôpital à la } \\
\text { Suite de l'Armeé }\end{array}$ & & \\
\hline 7 & Du Chirurgien Major du Port & LI & $\begin{array}{l}\text { Duties of the Chief Surgeon at the } \\
\text { Hospital }\end{array}$ \\
\hline 8 & $\begin{array}{l}\text { De l'Apoticaire entretenu dans } \\
\text { le port }\end{array}$ & LII & $\begin{array}{l}\text { Duties of the Apothecary at the } \\
\text { Hospital }\end{array}$ \\
\hline
\end{tabular}

Of the eight "Titres" of the Ordonnance, the six concerned with the Port Hospitals are thus not merely reproduced in the Admiralty Regulations, but they are reproduced in the same order.

The close similarity between the two documents becomes even more striking when the details of one Titre are compared with those of the corresponding Chapter. It is not proposed to give the whole of the Ordonnance, but examination of TITRE TROISIEME: Du Commissaire Préposé à la Direction de l'Hospital, will illustrate the point. The "articles" of this Titre are reproduced below in the order in which they occur in the Ordonnance, and they should be compared with the paragraphs of the Admiralty Regulations on pp. 136-138 above. Parts of the relevant pages of the French and Russian documents are shown in Figure 3.

\section{Ordonnance de Louis XIV: Livre Vingtieme: Titre Troisieme Du Commissaire Préposé à la Direction de l'Hospital}

Article I.

Le Commissaire prépost a la direction de l'Hospital, n'y fera recevoir aucun malade que sur le certificat du Medecin ou Chirurgien Major du Port, de la maladie ou blessure, il tiendra la main qu'il n'y soit receu que les Gardes de la Marine, Officiers mariniers, matelots, soldats et autres, que Sa Majesté veut y estre traitez, ainsi qu'il est expliqué cy-dessus en l'art. 5 du second Titre, et qu'ils en soient renvoyez aussi-tost qu'ils seront gueris.

II.

Il aura soin de faire tenir un rôle exact, par l'Ecrivain de l'Hospital, des malades qui y seront reçus, où il sera fait mention du lieu ou ils seront, de leur fonction, de la qualité de leurs maladies, et du jour de leur entrée et de leur sortie, par guerison ou par mort, pour justifier le temps qu'ils auront esté nourris dans l'Hospital.

III.

Il donnera les ordres nécessaires, pour faire balayer et nettoyer soigneusement l'Hospital, prendra garde que les malades et leurs lits soient tenus dans une grande netteté, faisant changer de draps aussi souvent qu'il conviendra, et qu'il soit bralé des parfums pour purifier l'air quand il sera jugé necessaire. 


\section{Basil Haigh}

IV.

Il se trouvera souvent dans l'Hospital aux heures du repas, et tiendra la main que l'Ecrivain n'y manque jamais, pour voir si les bouillons et autres alimens sont de bonne qualité, et s'ils sont donnez dans la quantité ordonnée, et que les Infirmiers ayent soin de les distribuer jour et nuit aux malades; il attestera et certifiera à la fin de chaque mois, le rôle des malades qui auront esté nourris, pour servir au payement des rations qui leur auront esté fournies.

V.

Il empeschera qu'il ne soit apporté aux malades des eaux de vie, vin, fruits, et autres choses défendues par le Medecin; qu'il ne leur soit rien donné à boire et a manger, dont l'Ecrivain n'ait connoissance, et qu'ils n'en puissent sortir sans permission.

VI.

Il attestera l'état des drogues et remedes qui seront fournis dans l'Hospital et dans la boutique, et en donnera tous les trois mois un certificat pour en recevoir le payement.

VII.

Il chargera l'Ecrivain des hardes et de l'argent des malades ou blessez qui seront reçus dans l'Hospital, et fera conserver le tout fort soigneusement, pour le leur rendre quand ils en sortiront, ou le remettre apres leur mort à leurs heritiers ou creanciers; et en cas qu'il ne se presente ny heritiers ny creanciers, il fera vendre les hardes, l'argent qui en proviendra, avec celuy qui aura esté trouvé dans les habits, sera employe suivant ce qui en sera ordonné par Sa Majesté, sur l'état que le Commissaire en remettra à la fin de chacune année.

VIII.

Le Commissaire aura soin de tenir un inventaire exact des lits, linges, meubles et ustenciles de l'Hospital, et de faire executer ponctuellement le traité fait avec celuy qui sera charge de leur fourniture et entretien.

IX.

Il fera embarquer sur les vaisseaux servans d'hospitaux à la suite des Armées ou Escadres, les lits, linges, meubles, ustenciles, rafraichissements et remedes ordonnez par Sa Majesté, et aura soin que le tout soit de bonne qualité, rangé en bon ordre et placé en lieu ou rien ne puisse gaster. Il retirera les certificats des Ecrivains des Hospitaux, de tout ce qui aura esté embarqué pour les malades, Officiers et gens de service qui y seront employez; se fera rendre compte des consommations à leur retour, et des rations fournies aux magazins, dont il remettra l'état à l'Intendant.

$\mathrm{X}$.

Il assistera aux examens qui se feront par les Medecin, et Chirurgien Major du Port, des Maistres et Aydes Chirurgiens et Apoticaires qui se presenteront pour servir sur les vaisseaux et dans Hospitaux; empeschera qu'il n'en soit reça que de capables des fonctions ausquelles ils seront destinez; sera present aux visites des remedes et ustenciles, dont seront composez les coffres de Chirurgie, qui seront embarquez sur les vaisseaux et Hospitaux de l'Armée, et observera qu'il y en ait la quantité ordonné, qu'ils soient de bonne qualité, et que les Maistres Chirurgiens soient pourvus de bons instrumens et de tous ceux qui leur sont necessaires.

XI.

Il se trouvera aus visites qui se feront des remedes, au retour des vaisseaux et Hospitaux, pour faire jetter ceux qui seront corrompus, et qui ne pourront pas servir une seconde campagne, et charger l'Apoticaire de ceux qui seront trouvez bons, dont il retira des reçus qu'il remettra à l'Intendant.

XII.

Il aura inspection sur les Officiers et gens de service, qui seront choisis et nommez par l'Intendant, pour servir les malades et blessez dans l'Hospital, et fera tenir un registre par l'Ecrivain du Roy, de leur entree et sortie, gages et nourriture, dont il dressera et certifiera l'état à la fin de chaque quartier, pour servir au payement de leurs gages et nourriture. 
XIII.

Il rendra compte tous les jours à l'Intendant, de tout ce qui regarde ses fonctions, des changemens qui arriveront dans l'Hospital, et de l'execution des traitez et reglemens de Sa Majesté, sur le fait de l'administration, police et depense de l'Hospital.

GENERAL COMPARISON OF THE "ORDONNANCE" AND "REGLAMENT"

Of the thirteen "Articles" in this section of the Ordonnance, three are concerned purely with hospital ships and are not relevant to the present task. Of the remaining ten, four are copied exactly, no more nor less, by the paragraphs of the Reglament, two are used in their entirety but supplemented by other details, while parts of two other "Articles" constitute the whole of the corresponding two paragraphs in the "Reglament". The correlation varies in the other sections. All of the nine Articles describing the duties of the clerk (Ecrivain) in the Ordonnance, for example, are reproduced verbatim in the Reglament, but three additional paragraphs are also given.

The contribution of the French "Ordonnance de Louis XIV" of 1698 to the "Reglament" of Peter the Great, enacted in 1722, is thus very considerable so far as the medical service for the navy and the shipyard workers is concerned.

\section{FATE OF THE ADMIRALTY REGULATIONS}

The extent to which the Admiralty Regulations were implemented and enforced is a problem too complex and too full of uncertainties to be considered adequately here. Veselago, ${ }^{12}$ the Russian naval historian, states: "Peter's Maritime Code and Admiralty Regulations, embracing all aspects of maritime activity at sea and in port, constituted a complete code of naval law; for many years they maintained in our fleet the forms established by its great founder and to some degree they helped to preserve the fighting strength of the fleet during the most troubled period of its existence". Yet the history of Russian legislation in general makes caution necessary in accepting that the Regulations were implemented in full or, indeed, at all. Without a meticulous examination of the problem it is impossible to state directly whether the medical arrangements stipulated by the Reglament did or did not materialize.

Nevertheless there is evidence that the Admiralty Regulations were used extensively in later years as the basis of legislative and administrative measures in various walks of life.

For example, the schedule of hours of work laid down by the Regulations was enforced at the metallurgical factories of the Urals, where equipment was manufactured for the navy, and at the new town of Ekaterinburg, the headquarters of the Siberian Mining Authority (Sibirskii Oberbergamt). ${ }^{13}$ Although in textile factories a fifteenhour day was stipulated by the "Regulations and work rules for cloth and kersey factories" of $1741,{ }^{14}$ it was later cut to thirteen hours as in the Admiralty Regulations,

12 Veselago, op. cit., note 8 above, p. 547.

13 Haigh, op. cit., note 4 above, p. 90.

14 PSZ-1, XI, No. 8440, 2 September 1741, St. Petersburg, 1830. 


\section{Basil Haigh}

and it remained at this level until 1803 , when it was further shortened by edict ${ }^{15}$ to twelve hours.

Turning to medical matters, the "General Regulations for Hospitals" of $1735^{16}$ lean heavily on the corresponding sections of the 1722 legislation and many of the items conclude with the words "from the Admiralty Regulations".

Finally, the influence of the Admiralty Regulations can be seen in the series of legislative and administrative codes drawn up by the Directors of the Siberian Mining Authority for the mining and metallurgical industry of the Urals: the precept (nakaz) of Wilhelm Hennin (1723), ${ }^{17}$ the factory code (zavodskii ustav) of V. N. Tatishchev $(1734)^{18}$ and, ultimately, the officially sponsored mining code (Gornoe Polozhenie) of 1806. ${ }^{19}$ The schedule of emoluments paid to servants of the Oberbergamt, including a senior and junior surgeon and other hospital staff, employed at Ekaterinburg states specifically that the arrangements were made "according to the Reglament".20

I am grateful to Professor Norman Hampson of the University of Newcastle upon Tyne for advice on the French "Ordonnances de la Marine".

${ }^{15}$ PSZ-1 XXVII, No. 21,074, 11 December 1803, St. Petersburg, 1830.

10 General'nyi Reglament o gospitalyakh $i$ o dolzhnostyakh, opredelennykh pri nikh Doktorov $i$ prochikh Meditsinskago china sluzhitelei, takzhe Kommisarov, pisarei, masterovykh, rabotnykh $i$ prochikh $k$ onym podlezhaschchikh lyudei, PSZ-1, IX, No. 6852, 24 December 1735, St. Petersburg, 1830.

${ }^{17}$ Haigh, op. cit., note 4 above, p. 98.

18 Ibid., p. 102.

10 Proekt gornago polozheniya (Project for mining regulations). PSZ-1, XXIX, No. 22,208, 13 July 1806, St. Petersburg, 1830.

${ }^{20} \mathrm{~W}$. Hennin, Opisanie ural'skikh $i$ sibirskikh zavodov (Description of the Urals and Siberian factories), 1735. Republished with a preface by Academician M.A. Pavlov and an introduction by M. F. Zlotnikov, Moscow, Istoriya Zavodov, 1937, p. 98. 